\title{
New records of the lancelet Branchiostoma lanceolatum in Scottish waters
}

\author{
M. O’Reilly ${ }^{1}$, S. Nowacki ${ }^{1}$, M. Baptie ${ }^{1}$, E. Gerrie ${ }^{1} \&$ M. MacKenzie ${ }^{2}$ \\ ${ }^{1}$ Scottish Environment Protection Agency, Angus Smith Building, 6 Parklands Avenue, Eurocentral, Holytown, North \\ Lanarkshire ML1 4WQ \\ ${ }^{2}$ Scottish Environment Protection Agency, Graesser House, Fodderty Way, Dingwall IV15 9XB \\ ${ }^{1}$ E-mail: myles.oreilly@sepa.org.uk
}

\begin{abstract}
New records of the lancelet Branchiostoma lanceolatum from Scottish waters are presented. Most of the records originate from sublittoral monitoring around fish farms from Orkney, Shetland, the Western Isles, the Isles of Skye and Mull, but also from a distillery discharge in the Firth of Clyde and a plankton survey in the Sea of the Hebrides. Lancelets were recovered in sediment grab samples from 6 - $60 \mathrm{~m}$ depth. Some recent accounts of intertidal lancelets are also cited. The lancelets appear to prefer coarser sediments and in the fish farm surveys were found predominantly at reference sites, away from the immediate influence of farm deposition.
\end{abstract}

\section{INTRODUCTION}

The lancelet Branchiostoma lanceolatum (Pallas, 1774) is an obscure, vaguely fish-like creature, up to $8 \mathrm{~cm}$ long, which lives buried in sand or coarse sediments in British seas. Its body is laterally compressed, pinkish white in colour, and pointed at both ends with a lancelike tail fin (Fig. 1). There are no paired fins, nor eyes, nor even a well-defined head, and it has only a small mouth surrounded by cirri, used to filter organic matter from the surrounding water. It has a dorsal notochord and segmented muscle blocks allowing it to swim in a sinusoidal fish-like manner, but no backbone, and it is therefore classified as an invertebrate (Barnes, 2015).

Lancelets are characteristic of sublittoral coarse sediments, so much so that a specific seabed habitat, "Amphioxus Sand" has been named after them, under their older genus name of Amphioxus (Pérèz \& Picard, 1964; De Biasi \& Boni, 2002). Nowadays, under the Marine Habitat Classification for Britain and Ireland, this biotope is known in full as "SS.SCS.CCS.Blan Branchiostoma lanceolatum in circalittoral coarse sand with shell gravel" (JNCC, 2018). Lancelets have a larval stage that lives for a short time within the plankton. The larvae metamorphose when around 3.5 - 5.0 mm long and the juveniles then settle on the seabed (Wickstead, 1967; Geise \& Pearse, 1975).

In U.K. waters, they are considered to be a southern species, with most records from south England and Wales. However, they have also been recorded off eastern England and Northern Ireland. They appear to be scarcer in Scottish waters with only scattered records on the west coast and in Orkney and Shetland (NBN, 2018).

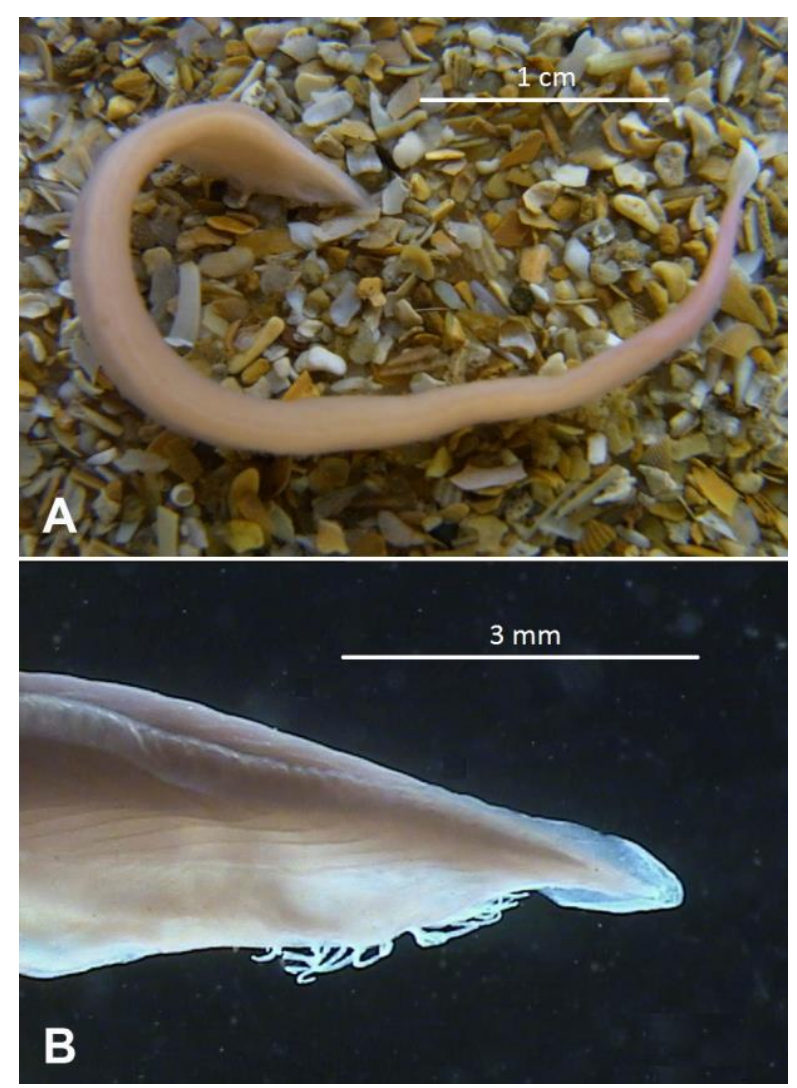

Fig. 1. The lancelet Branchiostoma lanceolatum. (A) A specimen captured in a SEPA survey in Laxfirth Voe, Shetland, 2011. The anterior is towards the left. (B) Anterior of the same lancelet showing the cirri around the mouth. (Photo: SEPA)

Records on the east coast of Scotland appear to be very sparse. The Fauna and Flora of St. Andrews Bay holds only one old record of a lancelet, from the stomach of a cod (Laverack \& Blackler, 1974).

Lancelets represent an evolutionary precursor of fish. They may be related to conodonts, enigmatic fossils, known from Carboniferous rocks in Scotland (Bergstrom et al., 1998; Knell, 2012). Fossils very similar to lancelets are known from the Cambrian period, at the dawn of vertebrate evolution. These include Pikaia gracilens from the famous Burgess Shale fauna in Canada (Gould, 1989; Briggs et al., 1994; Conway Morris, 1998) and Myllokunmingia fenjiaoa, 
one of the earliest putative vertebrates, from Chengjiang in China (Xian-Guang et al., 2017). Hence, lancelets are among a disparate group of "living fossils", which are known from the early fossil record and have survived, almost unchanged, for millions of years (Fortey, 2011).

They have long been an important model of vertebrate ancestors for university students studying evolution, and are still cultured for developmental biology studies (Desdevises et al., 2011; Theodosiou et al., 2011). However, outside of academia they are poorly known and frequently overlooked. Indeed Branchiostoma lanceolatum, the only lancelet species that occurs in British waters, was inadvertently omitted from the directory of British marine fauna and flora (Howson \& Picton, 1997).

\section{SURVEY AND METHODS}

In recent years, news snippets have highlighted occasional finds of lancelets in surveys by the Scottish Environment Protection Agency (SEPA) and Marine Scotland in Shetland and Orkney (O'Reilly, 2011; BBC, 2011). Some lancelets have also been found by others on shore surveys. One was captured at Cellardyke, Fife, during a Scottish Fisheries Museum children's rock pool guddle (Simon Hayhow \& Dr Richard Shelton, pers. comm. 2010); and two were spotted at Ord in Loch Eishort, Skye, at low tide on exposed maerl gravel, in a survey by South Skye Seas Initiative (Bailey, 2016; Skye Times, 2016).

Although lancelets have been regarded as rarely seen in Scottish waters, fish farm surveys carried out by SEPA and by farm operators have revealed numerous additional records, with further finds in similar surveys around a distillery discharge near Girvan.

SEPA requires fish farm operators to undertake selfmonitoring surveys of the seabed and since 2006 the survey data have been imported to a SEPA Fish Farm database. The database holds records from 2006 including 1,480 surveys with data from over 10,000 sampled stations with two, three, or five grabs at each station, depending on grab size. The benthic monitoring undertaken by the fish farm industry followed guidance outlined in SEPA's Fish Farm Manual. The manual was first issued in 1998 and the monitoring protocols have recently been updated (SEPA, 2017).

Benthic grab samples for macrofauna assessment are collected and sieved in the field on $1 \mathrm{~mm}$ mesh sieves to remove fine sediments, and the sieve residue is retained and fixed with the addition of formaldehyde solution. In the laboratory the samples are rinsed on $1 \mathrm{~mm}$ sieves to remove the formaldehyde. The residue is washed into trays and spread out to allow all the macrofauna to be picked out with forceps and placed in vials with preservative (industrial methylated spirit). All the macrofauna specimens are identified and counted with the aid of stereo and compound microscopes and standard taxonomic identification literature. The procedures for analysing macrofauna samples are now aligned with guidance laid down by the NMBAQC Scheme (Worsfold et al., 2010).

Most of the lancelet records derive from standard fish farm surveys with four stations sampled along a transect from the cage edge up to $100 \mathrm{~m}$ distance, and with two reference stations sampled at least $500 \mathrm{~m}$ away from the cages. The samples containing lancelets were collected in the sublittoral zone using grabs, usually $0.025 \mathrm{~m}^{2}$ or $0.02 \mathrm{~m}^{2}$ Van Veen grabs, but also $0.45 \mathrm{~m}^{2}$ Van Veen grabs, and occasionally $0.1 \mathrm{~m}^{2}$ Day or Hamon grabs. Usually five $0.025 \mathrm{~m}^{2}$ or $0.02 \mathrm{~m}^{2}$ replicate grabs were collected per station, but only three replicates for $0.45 \mathrm{~m}^{2}$ grabs or two for $0.1 \mathrm{~m}^{2}$ grabs. A couple of larval lancelets were collected during a SEPA plankton survey using a paired Bongo net $(23 \mathrm{~cm}$ diameter nets of mesh size $63 \mu \mathrm{m}$ and $200 \mu \mathrm{m}$ ) hauled vertically from $45 \mathrm{~m}$ depth.

\section{NEW LANCELET RECORDS}

In order to augment knowledge of lancelet distribution in Scottish seas, all the lancelet records held by SEPA have been collated and are presented, arranged geographically (approximately north to south), in Appendices 1 to 3 . There are over 70 new records from 59 different surveys, predominantly from Orkney and Shetland, but also from Eddrachillis Bay, Sutherland, the Western Isles, the Sea of the Hebrides, the Isles of Skye and Mull, and from Girvan in the Firth of Clyde.

The average depth of the grab sampling was around $20 \mathrm{~m}$, ranging from $6 \mathrm{~m}$ to $60 \mathrm{~m}$. The sediment descriptions are generally coarse, including sands, grit, shale, shell gravel, maerl, and stones, and are mostly consistent with the SS.SCS.CCS.Blan biotope typical for lancelets. The depth range of the new lancelet records, up to $60 \mathrm{~m}$, is deeper than the depths of "sublittoral to $30 \mathrm{~m}$ " quoted by Barnes (2015) and is more consistent with the depths of up to $80 \mathrm{~m}$ found by De Biasi \& Boni (2002). Cabioch (1961) found lancelets down to 100 m depth off Roscoff, Brittany, France.

The two SEPA records from the Sea of the Hebrides were for larval lancelets collected during plankton sampling. As the net is hauled from $45 \mathrm{~m}$ depth, the larvae could have been at any depth between 0 and $45 \mathrm{~m}$. The bathymetric depth at this site is around $90 \mathrm{~m}$ so, either way, these particular larvae were a considerable distance from the seabed.

On most grab sampling occasions, only a single lancelet was captured per grab sample, but sometimes a $0.045 \mathrm{~m}^{2}$ grab captured two lancelets. The most productive survey location by far was in the Sound of Hellisay, Barra, where, in a baseline survey in December 2010, 49 lancelets were captured in ten $0.1 \mathrm{~m}^{2}$ Day grabs, with two grabs capturing ten lancelets each. The mixture of mobile maerl and sand here seems to be favoured, with lancelets found at all five stations within the vicinity of the then proposed Hellisay fish farm. However, once the fish farm was established, subsequent surveys in 2013, 2015, and 2017 recorded no lancelets. 
There appear to be few previous records of lancelets in the Firth of Clyde. The NBN Atlas shows only a single record of a single lancelet, from August 2010, recorded in an SNH diving survey off Clauchlands Point, Lamlash Bay, Arran. The new finds of six lancelets from five stations around the Girvan distillery outfall in 2015 and 2016 may represent the most southerly records in Scottish waters.

\section{ANTHROPOGENIC IMPACTS}

On most of the fish farm surveys lancelets were found only at the reference sites, indicating they may be intolerant of organic deposition due to aquaculture. Their abundance close to the proposed fish farm at Hellisay in 2010 and subsequent disappearance from this area highlights their sensitivity to fish farm outputs. A study of an Amphioxus Sand community in Greece has shown that populations of lancelets diminish when exposed to organic enrichment, with accumulations of organic detritus altering the composition of all the infaunal community (Antoniadou et al., 2004). However, a study of lancelets in Italian waters found that, although populations had diminished in many areas, they still occurred in some sites with strong human impact with up to $20 \%$ silt and clay content in the sediments (De Biasi \& Boni, 2002). These authors also suggested that the presence of lancelets might be under-estimated due to their ability to burrow very rapidly in the coarser sediments, thus often avoiding being sampled, and to their unusual seasonal abundance pattern, with populations being reduced in spring and summer, when weather prospects mean scheduling of routine monitoring surveys may be more likely. They believed these biases could lead to inaccurate assessments of their prevalence. Fish farm surveys, which predominate here, are required to be carried out around peak biomass of the farmed fish, which should show no seasonal pattern, yet the surveys with lancelet records are more frequent in spring and summer (12 and 23 surveys) than autumn and winter (14 and 10 surveys). However, as only $4 \%$ of fish farm surveys actually recovered any lancelets, it would be unwise to draw any inference on their seasonal occurrence from surveys not specifically targeted towards their capture.

It is evident from the records provided, that lancelets are widely distributed in Scottish coastal waters, including both the intertidal and sublittoral zones. Tidally swept regions with course substrates, including shell gravel and maerl beds, offer a haven for them in many parts of Scotland and their prevalence here may be underestimated. However, both Amphioxus Sand and maerl habitats in which they prosper are potentially at risk from anthropogenic impacts.

Lancelets have been regarded as a southern species in U.K. waters and the preponderance of southern records in the U.K. NBN Atlas (NBN, 2018) supports this view. Indeed the addition of new records in Scottish waters might be considered as an indicator of warming seas. The world distribution of $B$. lanceolatum shown in the Marlin website (Barnes, 2015) implies that Shetland is at the northern edge of its distribution. However, historical records from Norway, collated by TambsLyche (1967), show that its distribution extends further northwards, with a single record from 1906 near Bodø, which lies just north of the Arctic Circle. Hence, the paucity of northern records in British waters and elsewhere is most probably just a consequence of limited sampling in suitable habitat.

\section{ACKNOWLEDGEMENTS}

Thanks are due to the fish farm companies: Cooke Aquaculture Scotland Ltd., Greig Seafood Shetland Ltd., Loch Duart Ltd., Marine Harvest (Scotland) Ltd., Scottish Sea Farms Ltd., and The Scottish Salmon Company for provision of data and sample analysts at Benthic Solutions (Jake Ganther), Biotikos (Inga Williamson), Fish Vet Group (Kate McEwen), Marine Farm Services, and Shetland Seafood Quality Control (Alan Harpin), for processing samples and identifying the fauna. The surveys at the Girvan distillery outfall were undertaken by Anderson Marine Surveys Ltd. and SAMS Research Services Ltd. and permission to use these data was given by William Grant \& Sons Ltd.

\section{REFERENCES}

Antoniadou, C., Krestenitis, Y. \& Chinteroglou, C. (2004). Structure of the "Amphioxus Sand" community in Thermaikos Bay (Eastern Mediterranean). Fresenius Environmental Bulletin 13(11a), 1122-1128.

Bailey, O. (2016). A fascinating find on the Scottish coastline. Fauna \& Flora International. News, 10th October 2016. https://www.fauna-flora.org/news/afascinating-find-on-the-scottish-coastline

Barnes, M.K.S. (2015). Branchiostoma lanceolatum Lancelet. In: Tyler-Walters, H. \& Hiscock, K. (Editors). Marine Life Information Network: Biology and Sensitivity Key Information Reviews. Marine Biological Association of the United Kingdom, Plymouth.

https://www.marlin.ac.uk/species/detail/85 Accessed 18/07/18.

BBC (2011). Marine surveys record 'brainless fish' off Orkney. BBC News website, 29th December 2011. https://www.bbc.co.uk/news/uk-scotlandhighlands-islands- 16346065

Bergström, J., Naumann, W.W., Viehweg, J. \& MartíMus, M. (1998). Conodonts, calcichordates and the origin of vertebrates. Mitteilungen der Museum für Naturkunde zu Berlin. Geowissenschaftliche Reihe 1, 81-92. https://doi.org/10.5194/fr-1-81-1998

Briggs, D.E.G., Erwin, D.H. \& Collier, F.J. (1994). The Fossils of the Burgess Shale. Smithsonian Institution Press, Washington, U.S.A.

Cabioch, L. (1961). Etude de la répartition des peuplements benthiques au large de Roscoff. Cahiers de Biologie Marine 2, 1-40.

Conway Morris, S. (1998). The Crucible of Creation. The Burgess Shale and the Rise of Animals. Oxford University Press, Oxford.

De Biasi, A.M. \& Boni, G. (2002). Branchiostoma lanceolatum (Leptocardia) along the Italian coasts: historical and new records. Atti della Società 
Toscana di Scienze Naturali - Memorie serie B 109 , 89-97.

Desdevises, Y., Maillet, V., Fuentes, M. \& Escriva, H. (2011). A snapshot of the population structure of Branchiostoma lanceolatum in the Racou Beach, France, during its spawning season. PLoS ONE 6(4): e18520. https://doi.org/10.1371/journal.pone.0018520

Fortey, R. (2011). Survivors. The Animals and Plants that Time has Left Behind. Harper Press, London.

Geise, A.C. \& Pearse, J.S. (Editors) (1975). Reproduction of Marine Invertebrates. Volume II Entoprocts and Lesser Coelomates. Academic Press, Cambridge, Massachusetts, U.S.A.

Gould, S.J. (1989). Wonderful Life. The Burgess Shale and the Nature of History. Hutchinson Radius, London.

Howson, C. \& Picton, B. (1997). The Species Directory of Marine Fauna \& Flora of the British Isles and Surrounding Seas. Ulster Museum and the Marine Conservation Society, Belfast and Ross-on-Wye.

JNCC (2018) The Marine Habitat Classification for Britain \& Ireland (v15.03). http://jncc.defra.gov.uk/MarineHabitatClassificatio n Accessed 26/7/18.

Knell, S.J. (2012). The Great Fossil Enigma: The Search for the Conodont Animal. Indiana University Press, Bloomington, U.S.A.

Laverack, M.S. \& Blackler, M. (1974). Fauna and Flora of St. Andrews Bay. Scottish Academic Press, Edinburgh.

NBN (2018). National Biodiversity Network Atlas. https://nbnatlas.org/ Accessed 18/7/18.

O'Reilly, M. (2011). Lancelet - the fish that never was - found in Scottish waters. Scottish Invertebrate News, The Scottish Invertebrate Conservation Newsletter Vol. 2, Issue 2, 11.

Pérèz, J.M., \& Picard, J. (1964). Nouveau manuel de bionomie benthique de la Mer Mediterranee. Recueil Travaux de la Station Marine d'Endoume, Bulletin 31,1-137.

SEPA (2017). Fish Farm Manual. https://www.sepa.org.uk/regulations/water/aquacult ure/fish-farm-manual/ Accessed 18/12/17.

Skye Times (2016). Rare find on Skye. http://theskyetimes.co.uk/index.php/734-rare-findon-skye Accessed 18/7/18.

Tambs-Lyche, H. (1967). Branchiostoma lanceolatum (Pallas) in Norway. Sarsia 29, 177-182. https://doi.org/10.1080/00364827.1967.10411078

Theodosiou, M., Colin, A., Schulz, J., Laudet, V., Peyrieras, N., Nicolas, J-F.,

Schubert, M., \& Hirsinger, E. (2011). Amphioxus spawning behavior in an artificial seawater facility. Journal of Experimental Zoology (Molecular and Developmental Evolution) 316, 263-275. https://doi.org/10.1002/jez.b.21397

Wickstead, J.H. (1967). Chordata, Sub-Phylum Acrania $=$ (Cephalochordata), Family: Branchiostomidae. Fiches d'Identification du Zooplancton. Sheet 111. Conseil lnternational pour I'Exploration de la Mer.

Worsfold, T.M., Hall, D.J. \& O'Reilly, M. (Editors) (2010). Guidelines for Processing Marine
Macrobenthic Invertebrate Samples: a Processing Requirements Protocol: Version 1.0, June 2010. Unicomarine Report to the NMBAQC Committee. 33pp. www.nmbaqcs.org

Xian-Guang, H., Siveter, D.J., Siveter, D.J., Aldridge, R.J., Pei-Yun, C., Gabbott, S.E. et al. (2017). The Cambrian Fossils of Chengjiang, China. The Flowering of Early Animal Life. (2nd edition). Wiley-Blackwell, Hoboken, New Jersey, U.S.A. 
Appendix 1. Lancelet (Branchiostoma lanceolatum) records from Shetland, Scotland.

\begin{tabular}{|c|c|c|c|c|c|c|c|}
\hline Survey & Date & Count & Station & Lat. (North) & Long. (West) & $\begin{array}{c}\text { Depth } \\
\text { (m) }\end{array}$ & Sediment description \\
\hline Wick of Belmont & $24 / 07 / 08$ & 1 & Ref.2 & $60^{\circ} 41.034^{\prime}$ & $00^{\circ} 58.101^{\prime}$ & 8 & Coarse sand, very coarse sand, shell gravel. \\
\hline Tur Ness & $30 / 08 / 07$ & 1 & $0-5 \mathrm{~m} \mathrm{CE}$ & $60^{\circ} 40.399^{\prime}$ & $00^{\circ} 52.964^{\prime}$ & 11 & Medium sand. \\
\hline Vee Taing & $23 / 03 / 12$ & 1 & Ref.2 & $60^{\circ} 40.040^{\prime}$ & $00^{\circ} 55.825^{\prime}$ & 19 & Coarse sand, shell fragments. \\
\hline Holm of Heogland & $20 / 08 / 13$ & 1 & $50 \mathrm{~m} \mathrm{~T} 2$ & $60^{\circ} 40.027^{\prime}$ & $00^{\circ} 56.223^{\prime}$ & 28 & Coarse sand, shell fragments. \\
\hline Holm of Heogland & $20 / 08 / 13$ & 1 & $50 \mathrm{~m} \mathrm{T1}$ & $60^{\circ} 39.980^{\prime}$ & $00^{\circ} 56.332^{\prime}$ & 29 & Shell/maerl fragments. \\
\hline Winna Ness & $27 / 01 / 11$ & 1 & $25 \mathrm{~m} \mathrm{NW}$ & $60^{\circ} 39.981^{\prime}$ & $00^{\circ} 54.480^{\prime}$ & 20 & Very fine to fine sand, shell fragments. \\
\hline Winna Ness & $15 / 02 / 13$ & 1 & Ref.1 & $60^{\circ} 39.979^{\prime}$ & $00^{\circ} 55.378^{\prime}$ & 26 & Medium sand, shell fragments. \\
\hline Winna Ness & $08 / 05 / 15$ & 1 & Ref.1 & $60^{\circ} 39.965^{\prime}$ & $00^{\circ} 55.877^{\prime}$ & 22 & Medium sand, broken shell. \\
\hline South Head of Mula & $19 / 10 / 09$ & 1 & Ref.2 & $60^{\circ} 39.967^{\prime}$ & $00^{\circ} 55.744^{\prime}$ & 21 & Medium to coarse sand, shell gravel. \\
\hline Djuba Wick & $12 / 08 / 08$ & 1 & Ref.2 & $60^{\circ} 37.486^{\prime}$ & $00^{\circ} 58.586^{\prime}$ & 21 & Coarse sand, shell fragments. \\
\hline Djuba Wick & $28 / 08 / 12$ & 1 & Ref.1 & $60^{\circ} 37.327^{\prime}$ & $00^{\circ} 59.590^{\prime}$ & 13 & Coarse sand, shell fragments with maerl. \\
\hline Djuba Wick & $28 / 08 / 12$ & 1 & Ref.2 & $60^{\circ} 37.198^{\prime}$ & $00^{\circ} 58.303^{\prime}$ & 19 & Coarse sand, shell fragments with maerl. \\
\hline Bow of Hascosay & 04/09/07 & 1 & Ref.1 & $60^{\circ} 35.862^{\prime}$ & $01^{\circ} 01.546^{\prime}$ & 24 & Coarse shell sand, maerl \\
\hline Bow of Hascosay & $01 / 09 / 09$ & 1 & Ref.1 & $60^{\circ} 37.105^{\prime}$ & $01^{\circ} 00.346$ & 13 & Coarse sand, shell fragments, maerl. \\
\hline Bow of Hascosay & $01 / 09 / 09$ & 1 & $50 \mathrm{~m} \mathrm{~W}$ & $60^{\circ} 36.603^{\prime}$ & $01^{\circ} 00.563$ & 13 & Coarse sand, shell fragments, maerl. \\
\hline Bow of Hascosay & $31 / 08 / 11$ & 1 & Ref.1 & $60^{\circ} 36.975^{\prime}$ & $01^{\circ} 00.443^{\prime}$ & 13 & Coarse shell sand, shell fragments, maerl. \\
\hline Bow of Hascosay & $31 / 08 / 11$ & 1 & Ref.2 & $60^{\circ} 36.192^{\prime}$ & $01^{\circ} 01.720^{\prime}$ & 18 & Mixed shell sand, maerl. \\
\hline Bow of Hascosay & $03 / 06 / 17$ & 1 & $350 \mathrm{~m} \mathrm{~N}$ & $60^{\circ} 36.907^{\prime}$ & $01^{\circ} 00.256^{\prime}$ & 9 & Maerl, sand. \\
\hline Wick of Vatsetter & 03/09/07 & 1 & Ref.1 & $60^{\circ} 35.862^{\prime}$ & $01^{\circ} 01.546^{\prime}$ & 24 & Coarse sand, shells, stones, maerl. \\
\hline Wick of Vatsetter & $30 / 08 / 11$ & 1 & Ref.1 & $60^{\circ} 35.828^{\prime}$ & $01^{\circ} 01.500^{\prime}$ & 25 & Medium to coarse sand, shell sand. \\
\hline Wick of Vatsetter & $30 / 08 / 11$ & 2 & Ref.2 & $60^{\circ} 36.192^{\prime}$ & $01^{\circ} 01.720^{\prime}$ & 18 & Shell sand, maerl. \\
\hline Wick of Vatsetter & $23 / 09 / 15$ & 1 & Ref.1 & $60^{\circ} 35.879^{\prime}$ & $01^{\circ} 01.630^{\prime}$ & 22 & Fine sand, shell fragments. \\
\hline Fish Holm & 02/09/09 & 1 & Ref.2 & $60^{\circ} 26.259^{\prime}$ & $01^{\circ} 07.568^{\prime}$ & 60 & Medium to coarse sand, shell fragments. \\
\hline Boatsroom Voe & $31 / 08 / 10$ & 1 & Ref.1 & $60^{\circ} 25.693^{\prime}$ & $01^{\circ} 06.414^{\prime}$ & 20 & Fine to medium sand, shell fragments. \\
\hline Laxfirth Voe & 03/04/09 & 1 & Ref.1 & $60^{\circ} 13.456^{\prime}$ & $01^{\circ} 10.834^{\prime}$ & 19 & Medium Sand. \\
\hline Laxfirth Voe & $09 / 07 / 11$ & 1 & Ref.3 & $60^{\circ} 13.457^{\prime}$ & $01^{\circ} 11.330^{\prime}$ & 17 & Sand and shell. \\
\hline Laxfirth Voe & $29 / 05 / 15$ & 1 & Ref.1 & $60^{\circ} 13.484^{\prime}$ & $01^{\circ} 10.820^{\prime}$ & 18 & Fine to coarse sand, shell fragments, maerl fragments. \\
\hline Laxfirth Voe & $21 / 11 / 16$ & 2 & Ref.1 & $60^{\circ} 13.480^{\prime}$ & $01^{\circ} 10.798^{\prime}$ & 18 & Fine or very fine sand, shell fragments, maerl fragments. \\
\hline Spoose Holm & 03/9/08 & 1 & Ref.1 & $60^{\circ} 07.964^{\prime}$ & $01^{\circ} 21.270^{\prime}$ & 22 & Shell gravel. \\
\hline Spoose Holm & $03 / 8 / 13$ & 3 & Ref.1 & $60^{\circ} 07.963^{\prime}$ & $01^{\circ} 21.269^{\prime}$ & 22 & Fine to medium sand, shell fragments. \\
\hline Spoose Holm & $09 / 9 / 17$ & 1 & Ref.1 & $60^{\circ} 07.918^{\prime}$ & $01^{\circ} 21.473^{\prime}$ & 27 & Medium to coarse sand, shell fragments. \\
\hline $\begin{array}{l}\text { Teisti Geo, Clift } \\
\text { Sound }\end{array}$ & $20 / 6 / 17$ & 1 & Ref.2 & $60^{\circ} 02.583^{\prime}$ & $01^{\circ} 19.473^{\prime}$ & 24 & Sandy gravel. \\
\hline
\end{tabular}


Appendix 2. Lancelet (Branchiostoma lanceolatum) records from Orkney, Scotland.

\begin{tabular}{|c|c|c|c|c|c|c|c|}
\hline Survey & Date & Count & Station & Lat. (North) & Long. (West) & Depth (m) & Sediment description \\
\hline Ouse Ness & $21 / 05 / 15$ & 1 & Ref.2 & $59^{\circ} 19.405^{\prime}$ & $02^{\circ} 56.877^{\prime}$ & 13 & Medium sand, shell fragments. \\
\hline Bay of Cleat & $14 / 12 / 10$ & 2 & Ref.2 & $59^{\circ} 18.663^{\prime}$ & $02^{\circ} 55.054^{\prime}$ & 13 & Medium sand, fine shell fragments, maerl. \\
\hline Bay of Cleat & 08/08/12 & 1 & $25 \mathrm{~m} \mathrm{SE}$ & $59^{\circ} 18.612^{\prime}$ & $02^{\circ} 55.536^{\prime}$ & 13 & Maerl, coarse shell sand. \\
\hline Bay of Cleat & $09 / 10 / 14$ & 1 & $25 \mathrm{~m} \mathrm{NW}$ & $59^{\circ} 18.747^{\prime}$ & $02^{\circ} 55.725^{\prime}$ & 17 & Fine sand, some maerl fragments. \\
\hline Eday Sound & $03 / 02 / 12$ & 1 & Ref.1 & $59^{\circ} 09.467^{\prime}$ & $02^{\circ} 44.647^{\prime}$ & 19 & Sand, shell, gravel and maerl. \\
\hline Eday Sound & $01 / 05 / 13$ & 2 & $50 \mathrm{~m} \mathrm{SE}$ & $59^{\circ} 09.585^{\prime}$ & $02^{\circ} 45.037^{\prime}$ & 17 & Shelly sand. \\
\hline Eday Sound & $01 / 05 / 13$ & 1 & $100 \mathrm{~m} \mathrm{SE}$ & $59^{\circ} 09.557^{\prime}$ & $02^{\circ} 45.022^{\prime}$ & 16 & Shelly sand. \\
\hline Kirk Noust, Rousay Sound & $17 / 05 / 13$ & 1 & Ref.1 & $59^{\circ} 09.077^{\prime}$ & $02^{\circ} 57.652^{\prime}$ & 15 & Fine sand, shell fragments, some maerl. \\
\hline Kirk Noust, Rousay Sound & $16 / 06 / 16$ & 1 & Ref.N & $59^{\circ} 09.129^{\prime}$ & $02^{\circ} 57.179^{\prime}$ & 10 & Sand, maerl. \\
\hline Wyre & $06 / 12 / 16$ & 1 & Ref.4 & $59^{\circ} 06.516^{\prime}$ & $02^{\circ} 58.990^{\prime}$ & 31 & Fine sand. \\
\hline Puldrite Bay & $24 / 04 / 08$ & 1 & Ref.1 & $59^{\circ} 03.002^{\prime}$ & $02^{\circ} 59.890^{\prime}$ & 15 & Fine sand, maerl fragments. \\
\hline Carness Bay & $11 / 05 / 10$ & 1 & Ref.2 & $59^{\circ} 00.732^{\prime}$ & $02^{\circ} 54.797^{\prime}$ & 13 & Coarse sand, shell fragments, stones, some maerl. \\
\hline Carness Bay & $18 / 10 / 16$ & 1 & Ref.2 & $59^{\circ} 00.609^{\prime}$ & $02^{\circ} 55.121^{\prime}$ & 6 & Coarse sand, shell sand. \\
\hline Carness Bay & $08 / 09 / 17$ & 1 & Ref.2 & $59^{\circ} 00.620^{\prime}$ & $02^{\circ} 55.128^{\prime}$ & 19 & Fine sand, shell sand. \\
\hline Yinstay East & $20 / 01 / 18$ & 1 & $200 \mathrm{~m} \mathrm{E}$ & $58^{\circ} 59.568^{\prime}$ & $02^{\circ} 49.344^{\prime}$ & 20 & Maerl, fine to medium sand, shell fragments. \\
\hline Scapa Flow & $25 / 05 / 14$ & 1 & W of Houten Head & $58^{\circ} 54.576^{\prime}$ & $03^{\circ} 13.902^{\prime}$ & 42 & Mud, maerl and stones. \\
\hline
\end{tabular}


Appendix 3. Lancelet (Branchiostoma lanceolatum) records from western Scotland

\begin{tabular}{|c|c|c|c|c|c|c|c|}
\hline Survey & Date & Count & Station & Lat. (North) & Long. (West) & Depth (m) & Sediment description \\
\hline Calbha Beag, Eddrachillis Bay & $24 / 06 / 10$ & 1 & $50 \mathrm{~m} \mathrm{NNE}$ & $58^{\circ} 17.088^{\prime}$ & $05^{\circ} 08.870^{\prime}$ & 25 & Sand and shell. \\
\hline Oldany Island, Eddrachillis Bay & $22 / 08 / 11$ & 1 & Ref.2 & $58^{\circ} 15.246^{\prime}$ & $05^{\circ} 16.561^{\prime}$ & 22 & Sand, shell. \\
\hline Oldany Island, Eddrachillis Bay & $17 / 02 / 16$ & 1 & T1 Ref.2 & $58^{\circ} 14.933^{\prime}$ & $05^{\circ} 16.256^{\prime}$ & 42 & Mud, sand, and shell. \\
\hline Loch Euphort, North Uist & $10 / 08 / 10$ & 1 & Ref.2 & $57^{\circ} 33.331^{\prime}$ & $07^{\circ} 09.803^{\prime}$ & 18 & Medium shell sand. \\
\hline Loch Euphort, North Uist & $11 / 04 / 12$ & 1 & $38 \mathrm{~m}$ AZE & $57^{\circ} 33.374^{\prime}$ & $07^{\circ} 10.061^{\prime}$ & 34 & Shale. \\
\hline Loch Euphort, North Uist & $12 / 02 / 14$ & 2 & Ref.1 & $57^{\circ} 33.316^{\prime}$ & $07^{\circ} 09.479^{\prime}$ & 21 & Mud, stones. \\
\hline Greanamul, Benbecula & $25 / 08 / 15$ & 1 & Ref.1 & $57^{\circ} 24.638^{\prime}$ & $07^{\circ} 11.180^{\prime}$ & 17 & Shale. \\
\hline Petersport, Benbecula & 28/07/10 & 3 & Ref.1 & $57^{\circ} 23.198^{\prime}$ & $07^{\circ} 13.707^{\prime}$ & 17 & Mud, shell, and sand. \\
\hline Petersport, Benbecula & $28 / 07 / 10$ & 1 & Ref.2 & $57^{\circ} 23.402^{\prime}$ & $07^{\circ} 14.076^{\prime}$ & 11 & Mud, shell, and sand. \\
\hline Petersport, Benbecula & $14 / 02 / 17$ & 1 & Ref.1 & $57^{\circ} 23.407^{\prime}$ & $07^{\circ} 14.144^{\prime}$ & 15 & Sand and gravel. \\
\hline Petersport, Benbecula & $12 / 07 / 17$ & 1 & Ref.1 & $57^{\circ} 23.407^{\prime}$ & $07^{\circ} 14.144^{\prime}$ & 16 & Sand, gravel, and shells. \\
\hline Hellisay, Barra & $17 / 12 / 10$ & 8 & $0 \mathrm{~m}$ & $57^{\circ} 00.345^{\prime}$ & $07^{\circ} 20.354^{\prime}$ & 26 & Maerl, sand. \\
\hline Hellisay, Barra & $17 / 12 / 10$ & 18 & $100 \mathrm{~m} \mathrm{~W}$ & $57^{\circ} 00.357^{\prime}$ & $07^{\circ} 20.462^{\prime}$ & 29 & Maerl, sand. \\
\hline Hellisay, Barra & $17 / 12 / 10$ & 3 & $200 \mathrm{~m} \mathrm{~W}$ & $57^{\circ} 00.374^{\prime}$ & $07^{\circ} 20.532^{\prime}$ & 28 & Maerl, sand. \\
\hline Hellisay, Barra & $17 / 12 / 10$ & 14 & $100 \mathrm{~m} \mathrm{E}$ & $57^{\circ} 00.342^{\prime}$ & $07^{\circ} 20.297^{\prime}$ & 27 & Maerl, sand. \\
\hline Hellisay, Barra & $17 / 12 / 10$ & 6 & $200 \mathrm{~m} \mathrm{E}$ & $57^{\circ} 00.356^{\prime}$ & $07^{\circ} 20.201^{\prime}$ & 24 & Maerl, sand. \\
\hline Loch Portree, Skye & $30 / 09 / 15$ & 2 & Ref.2 & $57^{\circ} 24.680^{\prime}$ & $06^{\circ} 09.361^{\prime}$ & 41 & Mud, sand. \\
\hline Sea of Hebrides & $17 / 08 / 15$ & 1 & South@Stn. 2 & $56^{\circ} 51.011^{\prime}$ & $06^{\circ} 27.721^{\prime}$ & $0-45$ & Plankton. \\
\hline Sea of Hebrides & $02 / 09 / 15$ & 1 & South@Stn. 2 & $56^{\circ} 51.011^{\prime}$ & $06^{\circ} 27.721^{\prime}$ & $0-45$ & Plankton. \\
\hline Geasgill, Mull & $12 / 05 / 06$ & 1 & $50 \mathrm{~m} \mathrm{~W}$ & $56^{\circ} 27.709^{\prime}$ & $06^{\circ} 10.247^{\prime}$ & 19 & Shells, grit, and stones. \\
\hline Girvan, Firth of Clyde & Aug-15 & 1 & Stn.7 & $55^{\circ} 16.012^{\prime}$ & $04^{\circ} 51.596^{\prime}$ & 11 & Very coarse sand. \\
\hline Girvan, Firth of Clyde & Aug-15 & 2 & Stn. 18 & $55^{\circ} 16.093^{\prime}$ & $04^{\circ} 51.394^{\prime}$ & 7 & Very coarse sand. \\
\hline Girvan, Firth of Clyde & Aug-15 & 1 & Stn.23 & $55^{\circ} 16.123^{\prime}$ & $04^{\circ} 51.621^{\prime}$ & 11 & Coarse sand. \\
\hline Girvan, Firth of Clyde & $29 / 07 / 16$ & 1 & Stn.31A & $55^{\circ} 16.403^{\prime}$ & $04^{\circ} 51.609^{\prime}$ & 13 & Mixed sediment. \\
\hline Girvan, Firth of Clyde & $29 / 07 / 16$ & 1 & Stn.31B & $55^{\circ} 16.416^{\prime}$ & $04^{\circ} 51.609^{\prime}$ & 13 & Mixed sediment. \\
\hline
\end{tabular}

